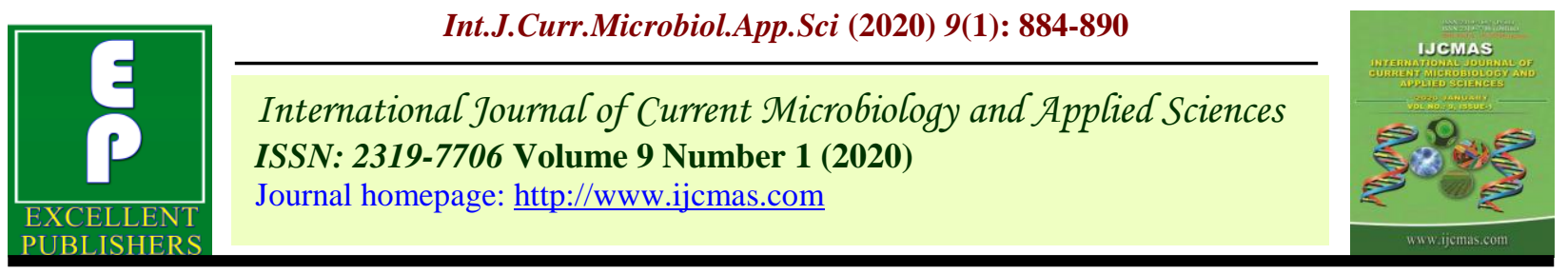

\title{
Detection of Virulence Genes in Aeromonas sobria Isolated from Diseased Fish Rohu, Labeo rohita by PCR
}

\author{
Chandra Bhushan Kumar*, Shilpa kumari, Anil Kumar, Shivanand, \\ Chinmayee Muduli, Vikash Sahu, S. M. Srivastava and Gaurav Rathore
}

ICAR-National Bureau of Fish Genetic Resources, Canal Ring Road, P.O. Dilkusha, Telibagh, Lucknow-226002, U.P., India

*Corresponding author

\section{A B S T R A C T}

\begin{tabular}{|l|}
\hline Ke y w o r d s \\
Aeromonas sobria, \\
Virulence genes, \\
Cytotoxic \\
enterotoxin, \\
Extracellular \\
hemolysin, Enolase, \\
Cytotonic \\
enterotoxin \\
\hline Article Info \\
\hline Accepted: \\
15 December 2019 \\
Available Online: \\
20 January 2020 \\
\hline
\end{tabular}

The Genus Aeromonas belongs to facultative, anaerobic gram negative bacteria. Several mesophilic species of Aeromonas cause septicaemia in a variety of aquatic organisms and gastrointestinal diseases in humans. The virulence of Aeromonas is considered multifactorial and are known to possess aerolysins, hemolysins, proteases, phospholipases, lipases, adhesions and enterotoxins. Therefore, the importance of present work lies in detecting the virulence genes in Aeromonas sobria isolated from diseased fish, rohu. The bacterium was identified using VITEK 2, automated bacterial identification system. Out of four genes screened, three genes namely, actA (cytotoxic enterotoxin), ahhlA (extracellular hemolysin) and enoA (enolase) were detected in $A$. sobria by PCR. However, astA gene which encodes for heat-stable cytotonic enterotoxin was not detected.

\section{Introduction}

The Genus Aeromonas comprises of a large group of species, which are Gram-negative, oxidase positive and facultative anaerobes. Aeromonas spp. are ubiquitous and their occurrence has been reported from fish, milk, meat, poultry and human beings. Several mesophilic species of Aeromonas cause septicaemia in a variety of aquatic organisms and gastrointestinal diseases in humans (Janda and Abbott, 1998). The virulence of Aeromonas is considered multifactorial and pathogenesis is complex (Sen and Rodgers, 2004). They possess many virulence factors such as aerolysins, hemolysins, proteases, phospholipase, lipase, adhesions and enterotoxins (Parker and Shaw, 2010). These genes responsible for virulence have also been found in Aeromonas isolated from municipally treated water (Sen and Rodgers, 2004). In fisheries context, bacterial problems 
are more commonly encountered in intensive fish culture because of deterioration of water quality and stress in the host, leading to manifestation of opportunistic pathogens, including Aeromonads (Syrova et al., 2018). Some of the mesophilic Aeromonads like $A$. hydrophila, A. veroni bv sobria A. bestiarum and $A$. salmonicida are reported as important fish pathogens (Kozinska, 2007).

The present study was aimed at identification of A. sobria using VITEK-2 system and detection of virulence genes of Aeromonas using PCR. The bacterium was isolated form diseased fish rohu, which is an important aquaculture fish in India. Therefore, the importance of the present work lies in assessing the virulence genes in A. sobria for determining its pathogenic potential.

\section{Materials and Methods}

\section{Bacterial isolation and genus phenotypic identification}

Using a sterile loop, kidney of a diseased rohu was streaked on non-selective agar medium, Trypticase soy agar (TSA) and agar plate was incubated at $28 \pm 2^{0} \mathrm{C}$ for $24 \mathrm{~h}$. Pure bacterial culture was used to perform biochemical tests like Gram staining, motility, oxidase, catalase, glucose utilization, salt tolerance and sensitivity to vibriostatic agent O/129 for presumptive identification of bacteria.

\section{VITEK-2 identification}

Single bacterial colony on TSA was used for bacterial identification using an automated bacterial identification system (VITEK 2 compact, BioMerieux, France).

\section{DNA extraction}

Total chromosomal DNA from A. sobria was prepared by thermal lysis of bacterial cells according to Martino et al., (2011) with slight modifications. Briefly, overnight grown fresh single colony was resuspended in $100 \mu \mathrm{l}$ triple distilled water, vortexed and heated at $94^{0} \mathrm{C}$ for $10 \mathrm{~min}$, followed by spinning. The supernatant of the lysed cells was used as DNA template in PCR.

\section{Detection of virulence factor genes}

Four pairs of reported primers (Table 1) were used for the detection of virulence genes; $a c t A$ (cytotoxic enterotoxin), astA, (heat-stable cytotonic enterotoxin), ahhlA (extracellular hemolysin) and enoA (enolase) using PCR. The PCR reactions consisted of initial denaturation at $94^{\circ} \mathrm{C}$ for $5 \mathrm{~min}$, followed by 35 cycles with denaturation at $94^{\circ} \mathrm{C}$ for $30 \mathrm{~s}$, annealing temperatures; $54^{\circ} \mathrm{C}$ for $30 \mathrm{~s}$ for aerA, $60^{\circ} \mathrm{C}$ for $30 \mathrm{~s}$ for astA, ahhlA and eno $A$, and extension at $72^{\circ} \mathrm{C}$ for $1 \mathrm{~min}$. A final extension step was carried out at $72^{\circ} \mathrm{C}$ for $10 \mathrm{~min}$. The PCR amplicons obtained were analysed on $1.5 \%$ agarose gel and observed under UV light.

\section{Results and Discussion}

\section{Bacterial isolation and identification}

Several buff-coloured colonies were observed on TSA medium after 24 hours of incubation and all were of similar morphological appearance. Four-colonies were randomly picked for biochemical characterization. All four colonies were Gram-negative, oxidasepositive, fermented glucose, showed absence of growth in $6.5 \%$ salt and were resistant to vibriostatic agent $\mathrm{O} / 129$. These characteristics presumptively indicate that the bacterium belonged to the family Aeromonadaceae. Several authors have reported similar kind of findings in presumptive identification of genus Aeromonas (Galbis et al., 2002; Abbott et al., 2003). Furthermore, VITEK 2 result also confirmed the identification of bacterium 
as $A$. sobria (Table 2). VITEK 2 an automated bacterial identification system provides rapid, reliable and highly reproducible results (Ling at al., 2001; Ling et al., 2003).

\section{Detection of virulence genes in $A$. sobria}

There are reports about clinical strains of $A$. sobria associated with humans infection (Wang et al., 2018) and possesses virulence associated factors (Daily et al., 1981). This bacterium has also been isolated from diseased fish, silver carp (Hypophthalmichthys molitrix) demonstrating 15\% prevalence rate (Dar et al., 2016). Motile mesophilic species of Aeromonas, particularly A. hydrphila and A. sobria cause septicaemia in cold-blooded animals including fish, reptiles, and amphibians (Janda and Abbott, 2010). The pathogenic potential associated factors have been correlated with the toxin coding genes in Aeromonas spp. which can be a predictor for pathogenicity (Heuzenroeder et al., 1999). Hussian et al., (2013) examined hemolytic strains of $A$. hydrophila, A. sobria and other Aeromonas spp. from fish and fishery products by the PCR amplification of ahhl and asal genes. Therefore, we were interested in determining the presence of potential virulence genes in Aeromonas sobria, isolated from diseased rohu fish. Out of four virulence factor genes screened, three genes, namely actA, ahhlA and enoA encoding for cytotoxic enterotoxin, extracellular hemolysin and enloase were detected in the bacterium, respectively. Sen and Rodgers (2004) determined the presence of six virulence factor genes in Aeromonas spp., viz. elastase $(a h y B)$, lipase (pla/lip/lipH3/alp-1) flagella A and B (flaA and flaB), the enterotoxins, act, alt and ast, using PCR. Out of 205 isolates tested, only one isolate contained all the virulence genes, others Aeromonas spp were having variety of combinations of these genes even in different strains of the same species. From our study, presence of these genes (actA, ahhlA and enoA) in A. sobria also indicates potential for virulence in rohu. Hence, further work is being carried for in-vivo experimental trails and its correlation with pathological changes.

Table.1 Primers used for amplification of different virulence factor genes

\begin{tabular}{|c|c|c|c|}
\hline $\begin{array}{l}\text { Name of the } \\
\text { gene }\end{array}$ & Primer sequence $\left(5^{\prime}-3^{\prime}\right)$ & $\begin{array}{l}\text { Size of } \\
\text { product }\end{array}$ & Reference \\
\hline $\begin{array}{l}\text { actA, } \\
\text { (Cytotoxic } \\
\text { enterotoxin) }\end{array}$ & $\begin{array}{l}\text { F- AGAAGGTGACCACCAAGAACA } \\
\text { R- AACTGACATCGGCCTTGAACTC }\end{array}$ & 232 & (Kingombe, 1999) \\
\hline $\begin{array}{l}\text { ast } A \text {, } \\
\text { (Heat-stable } \\
\text { cytotonic } \\
\text { enterotoxin) }\end{array}$ & $\begin{array}{l}\text { F- TCTCCATGCTTCCCTTCCACT } \\
\text { R- GTGTAGGGATTGAAGAAGCCG }\end{array}$ & 331 & $\begin{array}{l}\text { (Sen and Rodgers, } \\
\text { 2004) }\end{array}$ \\
\hline $\begin{array}{l}\text { ahh1A } \\
\text { (Extracellular } \\
\text { hemolysin) }\end{array}$ & $\begin{array}{l}\text { F- GCCGAGCGCCCAGAAGGTGAGTT } \\
\text { R- GAGCGGCTGGATGCGGTTGT }\end{array}$ & 130 & (Wang et al., 2003) \\
\hline $\begin{array}{l}\text { enoA } \\
\text { (Enolase) }\end{array}$ & $\begin{array}{l}\text { F- CGCCGACAACAACGTCGACATC } \\
\text { R- CTTGATGGCAGCCAGAGTTTCG }\end{array}$ & 598 & $\begin{array}{l}\text { (Martino et al., } \\
\text { 2011) }\end{array}$ \\
\hline
\end{tabular}


Table.2 Details of biochemical characteristics of Aeromonas sobria strain using VITEK 2 compact (BioMerieux, France)

\begin{tabular}{|c|c|}
\hline Biochemical test & Result \\
\hline Ala-Phe-Pro-arylamidase (APPA) & + \\
\hline L-Pyrrolydonyl- arylamidase (PyrA) & - \\
\hline L- Arabitol (IARL) & - \\
\hline Beta-galactosidase (BGAL) & + \\
\hline Beta -N- acetyl-glucosaminidase (BNAG) & + \\
\hline Glutamyl arylamidase pNA (AGLTp) & - \\
\hline Gamma-glutamyl transferase (GGT) & - \\
\hline Fermentation/glucose (OFF) & + \\
\hline Beta-glucosidase (BGLU) & - \\
\hline D-Maltose (dMAL) & + \\
\hline D-Mannitol (dMAN) & + \\
\hline D-Mannose (d MNE) & + \\
\hline Beta-xylosidase (BXY) & - \\
\hline Beta-alanine arylamidase pNA (BAlap) & - \\
\hline L-Proline arylamidase (ProA) & + \\
\hline Lipase (LIP) & - \\
\hline Palatinose (PLE) & - \\
\hline Tyrosine arylamidase (TyrA) & + \\
\hline Urease (URE) & - \\
\hline D-Sorbitol (dSOR) & - \\
\hline Saccharose /Sucrose (SAC) & + \\
\hline D- Tagatose (dTAG) & - \\
\hline D- Trehalose (dTRE ) & + \\
\hline Citrate (Sodium) (CIT) & - \\
\hline Malonate (MNT) & - \\
\hline 5-Keto -D- Gluconate (5KG) & - \\
\hline L- Lactate alkalinisation (ILATk) & + \\
\hline Alpha-glucosidase (AGLU ) & - \\
\hline Succinate alkalinisation (SUCT) & + \\
\hline Beta-N-acetyl-galactosaminidase (NAGA) & + \\
\hline Alpha- galactosidase (AGAL) & - \\
\hline Phosphatase (PHOS) & - \\
\hline Glycine arylamidase (GlyA) & - \\
\hline ORNITHINE DECARBOXYLASE (ODC) & - \\
\hline Lysine decarboxylase (LDC) & - \\
\hline L- Histidine assimilation (IHISa) & - \\
\hline Coumarate (CMT) & + \\
\hline Beta- glucoronidase (BGUR) & - \\
\hline O/129 resistance [ comp.vibrio.] (O129R) & + \\
\hline Glu-Gly-Arg-arylamidase (GGAA) & + \\
\hline L-Malate assimilation (IMLTa) & + \\
\hline Ellman (ELLM) & + \\
\hline L- Lactate assimilation (ILATa) & - \\
\hline Adonitol (ADO) & - \\
\hline $\mathrm{H}_{2} \mathrm{~S}$ production $\left(\mathrm{H}_{2} \mathrm{~S}\right)$ & - \\
\hline D- Glucose (dGLU) & + \\
\hline D-cellobiose (dCEL) & - \\
\hline
\end{tabular}


Figure 1

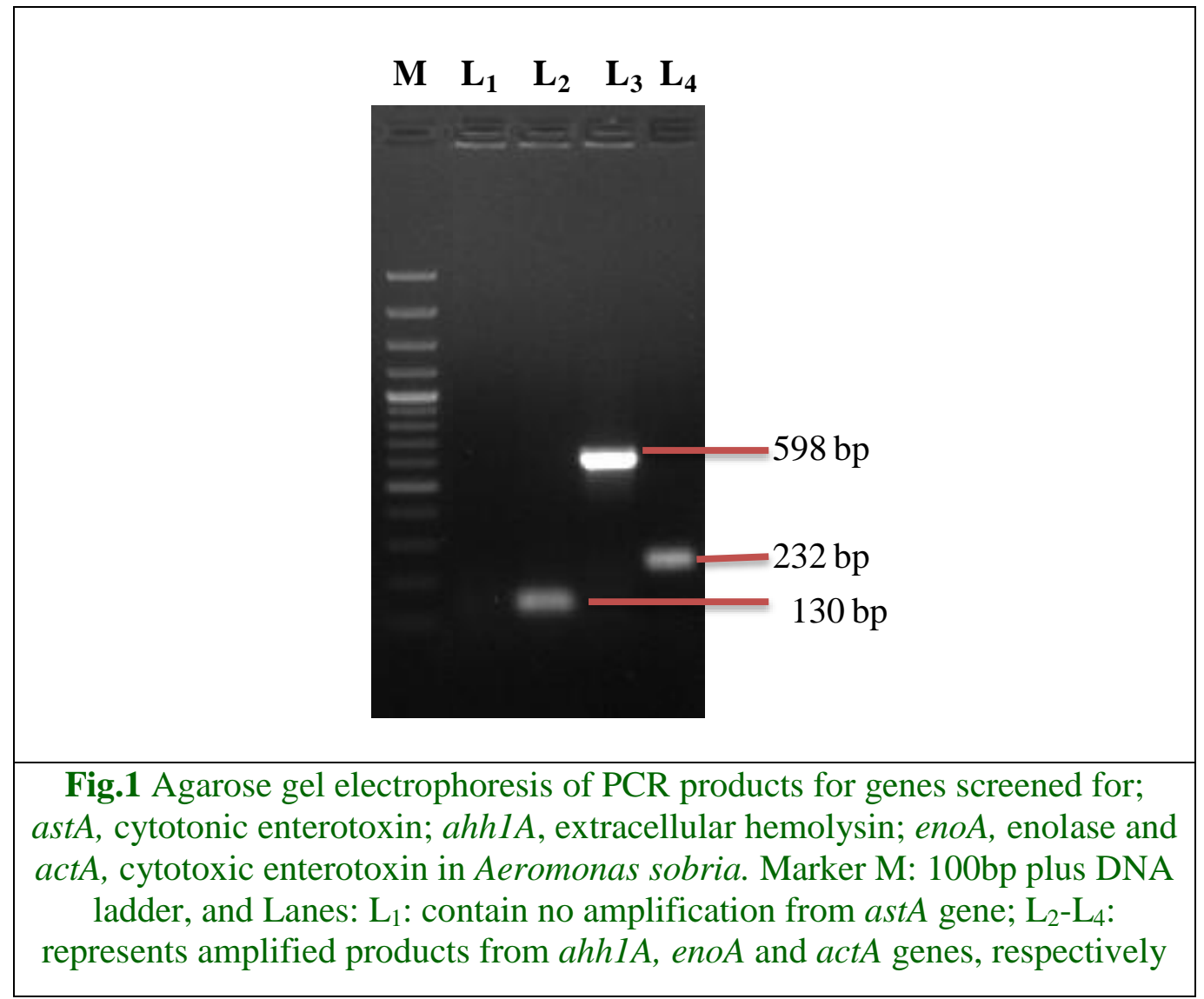

\section{Acknowledgements}

The authors would like to thank Dr. Kuldeep $\mathrm{K}$ Lal, Director, ICAR-NBFGR for his support and providing necessary infrastructure facility to carry out the work.

\section{References}

Abbott, S. L., W. K. Cheung and Janda, J. M. 2003. The genus Aeromonas: biochemical characteristics, atypical reactions, and phenotypic identification schemes. Journal of clinical microbiology. 41 (6): 2348-2357.

Daily, O.P., Joseph, S. W., Coolbaugh, J. C., Walker, R. I., Merrell, B. R., Rollins, D.M., Seidler, R.J., R. R. Colwell and Lissner, C. R. 1981. Association of
Aeromonas sobria with human infection. Journal of Clinical Microbiology. 13 (4): pp.769-777.

Dar, G. H., Dar, S. A., Kamili, A. N., M. Z. Chishti and Ahmad, F. 2016. Detection and characterization of potentially pathogenic Aeromonas sobria isolated from fish Hypophthalmichthys molitrix (Cypriniformes: Cyprinidae). Microbial pathogenesis. 91: 136-140.

Heuzenroeder, M. W., C. Y. Wong and Flower, R. L. 1999. Distribution of two hemolytic toxin genes in clinical and environmental isolates of Aeromonas spp.: correlation with virulence in a suckling mouse model. FEMS microbiology Letters. 174 (1): 131-136.

Hussain, I. A., Jeyasekaran, G., Shakila, R. J., K. T. Raj and Jeevithan, E. 2014. 
Detection of hemolytic strains of Aeromonas hydrophila and A. sobria along with other Aeromonas spp. from fish and fishery products by multiplex PCR. Journal of food science and technology. 51 (2): 401-407.

Janda, J. M., and Abbott, S. L. 1998. Evolving concepts regarding the genus Aeromonas: an expanding panorama of species, disease presentations, and unanswered questions. Clinical Infectious Diseases. 27 (2): 332-344.

Janda, J. M., and Abbott, S. L. 2010. The genus Aeromonas: taxonomy, pathogenicity, and infection. Clinical microbiology reviews. 23 (1): 35-73.

Kingombe, C. I. B., Huys, G., Tonolla, M., Albert, M. J., Swings, J., R. Peduzzi and Jemmi, T. 1999. PCR detection, characterization, and distribution of virulence genes in Aeromonas spp. Appl. Environ. Microbiol. 65 (12): 5293-5302.

Kozińska, A., 2007. Dominant pathogenic species of mesophilic Aeromonads isolated from diseased and healthy fish cultured in Poland. Journal of fish diseases. 30 (5): 293-301.

Ling, T. K., Tam, P. C., Z. K. Liu and Cheng, A. F. 2001. Evaluation of VITEK 2 rapid identification and susceptibility testing system against gram-negative clinical isolates. Journal of clinical microbiology. 39 (8): 2964-2966.

Ling, T. K., Z. K. Liu and Cheng, A. F. 2003. Evaluation of the VITEK 2 system for rapid direct identification and susceptibility testing of gram-negative bacilli from positive blood cultures. Journal of clinical microbiology. 41 (10): 4705-4707.

Martino, M. E., Fasolato, L., Montemurro, F., Rosteghin, M., Manfrin, A., Patarnello, T., E. Novelli, and Cardazzo, B. 2011.
Determination of microbial diversity of Aeromonas strains on the basis of multilocus sequence typing, phenotype, and presence of putative virulence genes. Appl. Environ. Microbiol. 77 (14): 4986-5000.

Miñana- Galbis, D., Farfán, M., J. G. Lorén and Fusté, M. C. 2002. Biochemical identification and numerical taxonomy of Aeromonas spp. isolated from environmental and clinical samples in Spain. Journal of applied microbiology. 93 (3): 420-430.

Parker, J. and Shaw, J. 2010. Aeromonas spp. clinical microbiology and disease. Journal of Infection. 20: 1-10.

Sen, K., and Rodgers, M. 2004. Distribution of six virulence factors in Aeromonas species isolated from US drinking water utilities: a PCR identification. Journal of applied microbiology. 97 (5): 10771086.

Syrova, E., Kohoutova, L., Dolejska, M., Papezikova, I., Kutilova, I., Cizek, A., Navratil, S., H. Minarova and Palikova, M., 2018. Antibiotic resistance and virulence factors in mesophilic Aeromonas spp. from Czech carp fisheries. Journal of applied microbiology.125 (6): 1702-1713.

Wang, D., Sun, F., Li, Z., Y. Hu and Xu, R. 2018. Acute septic arthritis of shoulder joint caused by Aeromonas veronii biotype sobria. Der Orthopäde. 47 (12): 1024-1027.

Wang, G., Clark, C. G., Liu, C., Pucknell, C., Munro, C. K., Kruk, T. M., Caldeira, R., D. L. Woodward and Rodgers, F. G., 2003. Detection and characterization of the hemolysin genes in Aeromonas hydrophila and Aeromonas sobria by multiplex PCR. Journal of clinical microbiology. 41 (3): pp.1048-1054. 


\section{How to cite this article:}

Chandra Bhushan Kumar, Shilpa kumari, Anil Kumar, Shivanand, Chinmayee Muduli, Vikash Sahu, S. M. Srivastava and Gaurav Rathore. 2020. Detection of Virulence Genes in Aeromonas sobria Isolated from Diseased Fish Rohu, Labeo rohita by PCR. Int.J.Curr.Microbiol.App.Sci. 9(01): 884-890. doi: https://doi.org/10.20546/ijcmas.2020.901.098 